Article

\title{
For Sustainable Application of Mobile Learning: An Extended UTAUT Model to Examine the Effect of Technical Factors on the Usage of Mobile Devices as a Learning Tool
}

\author{
Saud S. Alghazi ${ }^{1,2, *}$, Amirrudin Kamsin ${ }^{3}$, Mohammed Amin Almaiah ${ }^{4}\left(\mathbb{D}\right.$, Seng Yue Wong ${ }^{5}(\mathbb{D}$ and \\ Liyana Shuib ${ }^{1, * \text { (D) }}$ \\ 1 Department of Information Systems, Faculty of Computer Science \& Information Technology, University of \\ Malaya, Kuala Lumpur 50603, Malaysia \\ 2 Department of Computer Science, Faculty of Computer Science \& Engineering, Hail University, \\ Hail 55476, Saudi Arabia \\ 3 Department of Computer System \& Technology, Faculty of Computer Science \& Information Technology, \\ University of Malaya, Kuala Lumpur 50603, Malaysia; amir@um.edu.my \\ 4 Department of Computer Networks and Communications, College of Computer Sciences and Information \\ Technology, King Faisal University, Al-Ahsa 31982, Saudi Arabia; malmaiah@kfu.edu.sa \\ 5 Centre for Internship Training and Academic Enrichment (CITrA), University of Malaya, \\ Kuala Lumpur 50603, Malaysia; wongsengyue@um.edu.my \\ * Correspondence: saud@siswa.um.edu.my (S.S.A.); liyanashuib@um.edu.my (L.S.); \\ Tel.: +(60)-03-79676415 (S.S.A.); +(60)-11-276-16415 (L.S.)
}

Citation: Alghazi, S.S.; Kamsin, A.; Almaiah, M.A.; Wong, S.Y.; Shuib, L. For Sustainable Application of Mobile Learning: An Extended UTAUT Model to Examine the Effect of Technical Factors on the Usage of Mobile Devices as a Learning Tool. Sustainability 2021, 13, 1856.

https://doi.org/10.3390/su13041856

Academic Editor: Kris Law

Received: 3 January 2021

Accepted: 2 February 2021

Published: 8 February 2021

Publisher's Note: MDPI stays neutral with regard to jurisdictional claims in published maps and institutional affiliations.

Copyright: (c) 2021 by the authors. Licensee MDPI, Basel, Switzerland. This article is an open access article distributed under the terms and conditions of the Creative Commons Attribution (CC BY) license (https:/ / creativecommons.org/licenses/by/ $4.0 /)$.

\begin{abstract}
Mobile devices have become an important tool in higher education. Although mobile devices have several benefits for students, the use of these devices is still very limited among students. This low percentage of usage could be attributed to several reasons, both technical and non-technical. Therefore, there is a need to conduct more research in order to understand the necessary factors that would lead to enhanced student usage, thus achieving sustainable mobile learning. In order to achieve that, our study proposes a model by employing the unified theory of acceptance and use of technology (UTAUT) to investigate the necessary factors that influence intention to use mobile learning among university students. To evaluate the proposed model, structural equation modelling (SEM) was employed to analyze data collected from 612 students. The results indicated that factors, such as device connectivity, device compatibility, device memory, device performance, network coverage, and network speed have a significant and positive influence on students' intention to use mobile learning. This research provides important recommendations for university decision makers and developers on understanding the necessary factors for adopting mobile learning and reflect the students' requirements.
\end{abstract}

Keywords: mobile learning; technical factors; mobile learning acceptance model; TAM; UTAUT

\section{Introduction}

Tremendous developments in mobile technology and applications have encouraged people to use them in their day-to-day life. In addition, the number of mobile device subscribers has increased significantly in recent years [1]. The increase in subscribers due to several benefits, functions and services offered by mobile devices make our life easier. Historically, mobile devices and associated technology continue to develop exponentially, helping users complete tasks quickly, perform transactions, access the Internet to find information, and for entertainment [2].

By 2019, mobile phones were in use almost everywhere, with users becoming more attached to these devices for work, communication, and pleasure [3]. Given the growth of this technology, the use of the Internet has become commonplace in the lives of people worldwide, not just to communicate, but also to watch video broadcasts and make video 
calls. However, the quality of such applications may be affected by the number of people connected to the mobile network [4]. Indeed, at present, the use of fifth-generation networks, such as $5 \mathrm{G}$, is emerging, driven by previous generations of networks that helped with the adoption of and growth in the use of mobile devices, such as smartphones. For instance, in fourth-generation networks, such as $4 \mathrm{G}$, notable developments and advancements have been made in numerous domains, such as multimedia, video broadcasting, data transmission, and security, in reaching users in many parts of the globe through different types of devices [5].

\section{Problem Statement}

Despite the many studies that have been conducted on mobile learning, more research is still needed to investigate the attitude of students towards mobile learning [6]. Conducting more research in this domain will help researchers gain a better understanding of how to exploit this smart technology in education [7]. Despite the several benefits of mobile devices, they still have limitations that affect students' acceptance of this new technology [8]. This aspect has motivated researchers to address these limitations. For instance, applying this type of technology in education will help learners achieve the optimal use of such devices to enhance their knowledge and learning ability [9]. Several universities across the world have integrated m-learning into their settings, but they still face several problems that prevent students from exploiting mobile learning systems in an optimal way [10]. These obstacles may be related to technical and non-technical aspects, such as device capability, network coverage, facilitating conditions, social influence, and others [2]. In addition, acceptance of mobile learning among students is considered an important step to ensuring the success of mobile learning implementation [8]. However, the slow adoption of m-learning has been considered a technical issue rather than an educational problem [9]. Therefore, there is a need to identify key technical factors that could help motivate students to use mobile learning systems in their education [11].

Incorporating new technology, such as m-learning, should be supported by community acceptance before applying such technology [7]. However, while the power associated with technology acceptance models is evident in many countries worldwide, research is limited in the context of developing countries, especially Arab countries, to measure the adoption and use of technology [12]. In addition, there are limited studies that focus on the technical aspects that affect the adoption of m-learning, such as performance, compatibility, connectivity, security and reliability, processing power, memory and other factors [13]. Therefore, there is a need to develop a model that measures the acceptance of m-learning amongst students based on the technical aspects, especially in the context of Arabic countries. Accordingly, this study aims to fill this gap by exploring and understanding the technical aspects and factors that could motivate learners to exploit the capabilities of mobile devices as a learning tool in the higher education environment.

\section{Background}

\subsection{Concept of Mobile Learning}

Given the emergence of technology and its introduction and application in education, many elements of technology have been included and adopted in the educational learning process. Previously, teachers were the sole source of information for students. However, given the introduction and advancements of modern technology, especially mobile phones, this has become a key resource in the education system. Several definitions that describe this technology have emerged over the years by many researchers. Mobile learning or mlearning by its very definition is described as the delivery of any educational content to the recipient that is developed and used by mobile devices, whether it is specific information or a full curriculum [14]. Several studies have indicated that the acceptance of mobile learning by students is the critical step in order to increase the use of this technology [15].

Given the advancements of smart devices, m-learning technology is still considered as a secondary method of learning: The role of the teacher still forms the basis of learning 
due to several social and technical considerations [5]. Despite this, results from previous studies have shown that many students still have the desire to use mobile devices since it enhances the speed of communication with their teachers and colleagues more than the traditional methods currently available [16]. Moreover, m-learning makes the education process more acceptable to students, especially among the younger generation who are more likely to pursue and use new technology [17]. Indeed, m-learning allows students to learn independently without the need for teachers, which increases their level of interaction with other users and information [18]; it is also not necessary to carry out this operation in the same place, but anywhere and at any time [19]. Interestingly, university students tend to use their mobile phones to communicate with each other without having noticeable problems in the learning process [20].

Furthermore, m-learning allows learners to make the most of their time investment [21]. Nowadays, it is no longer necessary to receive information only in a physical classroom environment, so there remains a need to include mobile devices in the process of obtaining knowledge and learning regardless of the demographics at a reasonable cost [22]. The m-learner may also face certain challenges when moving from one country to another, where mobile and network standards may differ [5]. Likewise, when m-learning is incorporated into the education process in developing countries, users may also encounter difficulties in its application, such as technical problems [6,23]. One study indicated that when students practice different types of teaching, such as flipped learning, teachers show a moderate degree of proficiency to qualify them to use digital technologies [24]. Moreover, some educational materials developed for the use on desktop devices or laptops may not be appropriate or compatible for smart devices or phones used by students or learners unless modifications are made to cater for both platforms [25]. This problem has been resolved with many educational platforms currently supporting both a desktop view and a mobile view.

\subsection{Related Studies on M-Learning}

Despite numerous studies that have been conducted in the area of mobile learning, technical factors have not always been considered [13]. Many of these studies have employed various acceptance models, such as applying original models, while others employed altered models. One such study found that despite what students may benefit from in relation to the services provided through mobile education and the importance of their acceptance of this type of education, the acceptance of this type of education remains relatively low in some Arab countries [26]. One of the incentives to use mobile education is the ease of access to material regardless of physical constraints and time, especially if there is a high level of confidence of users and that this form of education is compatible with students' devices [27]. Some researchers have proposed the use of the mobile learning adoption model (MLAM) and have found that technological self-efficacy is an important factor in encouraging students to accept m-learning [27]. In another study, it was found that one of the factors leading to the success of mobile education among students coincides with the universities' knowledge in applying this type of education and taking advantage of its capabilities [28]. Although the choice to learn using mobile devices is in the hands of students, there is still a need to investigate the factors that affect students' acceptance of mobile education [29]. As mentioned, the acceptance of mobile education among students is still relatively low in some Arab countries [30]. Therefore, there is needed to identify the necessary factors that would encourage students to use mobile learning effectively. Some researchers have developed a model that integrates the technology acceptance model (TAM) with the updated DeLone and McLean's model (DL \& ML) and have found that among the factors affecting students' intention to explore such new technology is the quality of this type of m-learning [31]. Prior to introducing new digital technologies for use by students, the factors that affect the effectiveness and efficiency of teaching using these technologies must be known [32]. 
However, despite the emergence of mobile learning after e-learning, studying the extent of learners' acceptance of e-learning itself remains limited in Saudi Arabia and as such, requires further research [33]. Moreover, when a student becomes more confident in using this type of technology, it will increase their need and use in academic life [34]. Some studies have concluded that when embarking on the inclusion of mobile education, it is necessary to consider issues technically, educationally, socially and individually [35]. There is no doubt that technology is important in the lives of individuals, but how learners view and use this technology is also important, which to date has remained unexplored [36].

\section{Overview of Technology Acceptance Models}

Many researchers have employed different technology acceptance models, such as the technology acceptance model (TAM), the unified theory of acceptance and use of technology (UTAUT), and others, in their studies. Among the most popular and widely used models is the TAM, developed in 1989, and the UTAUT, which was introduced by Venkatesh et al. in 2003. These are shown in Figure 1 [12]. The TAM model was developed to measure the behavioural aspect of a user's attitude toward computers [37] and demonstrated a variety of uses according to the attitudes and beliefs of researchers. It consists of four reflective factors, namely performance expectancy, effort expectancy, social influence, and facilitating conditions. Moreover, the TAM has been included in numerous studies and research to measure users' acceptance of the inclusion of technology in the educational process, though the majority of these studies revolved around the teacher [38]. In contrast, another of the popular models, the UTAUT, was developed based on eight theories, namely, the theory of reasoned action (TRA), TAM, motivation model (MM), theory of planned behavior (TPB), combined TAM and TPB (C-TAM-TPB), model of PC utilization (MPCU), innovation diffusion theory (IDT), and social cognitive theory (SCT) [39]. UTAUT was found to outperform many of the previous theories [40]. In addition, in a recent review conducted to study technology and acceptances models between 2010 and 2020, UTAUT was found to be the most used model [23]. As a result, in the present research, we adopted the UTAUT model as the basis for the proposed model developed in this study.

\section{The Importance of Technical Factors on Mobile Learning Acceptance}

While many factors have been investigated and considered in previous models, many technical factors have been highlighted that could affect the acceptance of students learning using mobile technology. Further to the factors associated with the human psyche, mlearning is still considered to help in the learning process, but not necessarily as the primary method of learning [41]. Nonetheless, a large proportion of students believe that communicating with their teachers and colleagues is distinctly faster if it is conducted via smart devices (i.e., a smartphone) [42], leading to a changing in attitude by students toward m-learning [6]. However, m-learning faces many challenges, which are categorized into five types: Technical, security, social, pedagogical, and challenges in the context of developing countries [43].

These challenges are due to different technical standards between countries [44] Some of these challenges arise, for example, in African countries where the technological infrastructure is inadequate [45]. Although many studies have measured the technology acceptance of recipients, there remain deficiencies in those studies in the context of Arab countries, which is a limiting factor regarding cultural values and the extent of the impact on technology acceptance in these countries [16]. Therefore, given these challenges and the limited investigation of the technical factors, we formulated our following hypotheses using the proposed model adopted from UTAUT. The unified theory of acceptance and use of technology (UTAUT) with the TAM model is considered one of the most cited models in the area of using technology [46]. As well as, UTAUT was found to outperform many of the previous theories [40]. As mentioned before, in a recent review conducted by some researchers to study technology and acceptances models in the last decade, UTAUT was 
found the most used model [23]; therefore, UTAUT model was relied upon because it is the latest.

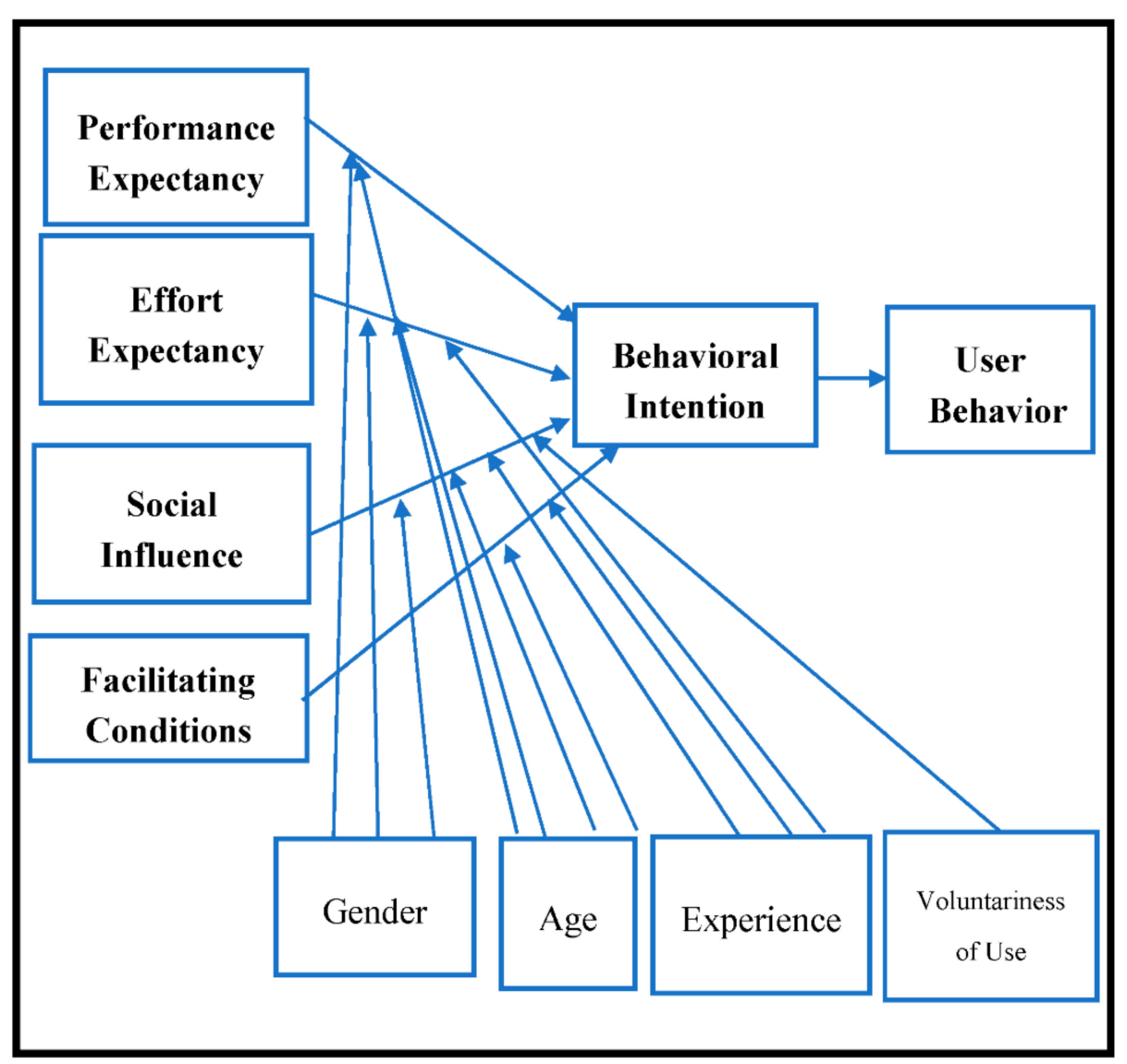

Figure 1. Unified theory of acceptance and use of technology (UTAUT) model by Venkatesh et al. (2003).

\section{Proposed Model and Hypotheses}

From the above discussion in the literature section, we found that there is critical need to propose a new model in order to capture the most important technical factors to enhance students' intention to use mobile learning. Based on that, we used the UTAUT model in establishing our model in this study. The proposed model includes 12 hypotheses that will be tested (vide infra).

\subsection{Performance Expectancy}

Performance expectancy is defined as 'the degree to which an individual believes that using the system will help him or her attain gains in job performance' [40]. We use an adopted definition here and define performance expectancy as the degree to which a student thinks that using mobile learning will increase their ability to gain knowledge.

H1. Performance expectancy has a significant influence on the intention to use m-learning among students at the University of Hail.

\subsection{Effort Expectancy}

According to the original UTAUT model regarding effort expectancy, the definition is 'the degree of ease associated with the use of the system' [40]. Integrating mobile technology into learning leads us to define effort expectancy as the degree of ease associated with the use of mobile technology in the learning process. 
H2. Effort expectancy has a significant influence on the intention to use m-learning among students at the University of Hail.

\subsection{Social Influence}

Social influence is defined as 'the degree to which an individual perceives that others think it is important that they should use the new system' [40]. According to the original definition of this factor, we redefine it to be the degree to which a student believes that the important surrounding community encourages the use of m-learning.

H3. Social influence has a significant influence on the intention to use m-learning among students at the University of Hail.

\subsection{Price Value}

Price has many meanings and uses according to different aspects. However, according to some definitions, it can mean that the perceived benefit of using technologies compared to the associated cost [47]. In addition, 'price can be both an indicator of the amount of sacrifice needed to purchase a product and an indicator of the level of quality' [48]. Therefore, this term is defined in this study as the student's belief that the value of mobile technology is reasonable to use as a learning tool.

H4. Price value has a significant influence on the intention to use m-learning among students at the University of Hail.

\subsection{Device Connectivity}

Connectivity is 'a word used to describe how well hardware or software devices can communicate with a range of other devices' [49]. In the learning process using mobile technology, it can be defined as the ability to learn through mobile technology by communicating with several devices in several different places.

H5. Device connectivity has a significant influence on the intention to use in m-learning among students at the University of Hail.

\subsection{Device Compatibility}

According to some researchers 'compatibility standards assure the user that a component or sub-system can be successfully incorporated and be "inter-operable" with other constituents of a more extensive system of closely specified inputs and outputs' [50]. Under the proposed model, it is defined as the ability of the user to use the mobile device to learn through several platforms or programs, regardless of the different sources.

H6. Device compatibility has a significant influence on the intention to use m-learning among students at the University of Hail.

\subsection{Device Security and Reliability}

Mobile device security is defined as 'the measures taken to protect sensitive data stored on portable devices' [51]. In this study, it can be defined as the student's belief that the data are protected and highly reliable while using it for m-learning.

H7. Device security and reliability have a significant influence on the intention to use m-learning among students at the University of Hail.

\subsection{Device Processing Power}

A processor can be described as 'the electronic device which performs calculations' [52]. In the proposed model, a mobile processor can accomplish calculation tasks that make learning through mobile technology easy and flexible.

H8. Device processing power has a significant influence on the intention to use m-learning among students at the University of Hail. 


\subsection{Device Memory}

Computer memory is 'any physical device capable of storing information temporarily, like RAM (random access memory), or permanently, like ROM (read-only memory). Memory devices utilise integrated circuits and are used by operating systems, software and hardware' [53]. We define device memory as the mobile's ability to absorb, store, and transfer educational media of various sizes.

H9. Device memory capacities have a significant influence on the intention to use m-learning among students at the University of Hail.

\subsection{Device Performance}

Performance can be described as 'the accomplishment of a given task measured against presently known standards of accuracy, completeness, cost and speed' [54]. By using mobile technology in education, device performance can be defined as the accomplishment of learning tasks through mobile devices in a specified period and time according to known standards.

H10. Device performance has a significant influence on the intention to use m-learning among students at the University of Hail.

\subsection{Network Coverage}

The Internet is defined as: 'A global network of networks used to exchange information using the TCP/IP protocol. It allows for electronic mail and accessing and retrieval of information from remote sources' [52]. Here, we redefine network coverage as the ability to use mobile devices to access the network from various places in order to learn.

H11. Network coverage has a significant influence on the intention to use m-learning among students at the University of Hail.

\subsection{Network Speed}

The issue of network speed has been raised in numerous forums over the past few decades and has become a factor driving competition among communication companies. In our study, it is defined as the speed of communication via a mobile device (i.e., a smartphone) and the length of time required to complete the learning process, which involves browsing, downloading, and sending educational materials. Figure 2 shows the proposed model.

H12. Network speed has a significant influence on the intention to use m-learning among students at the University of Hail. 


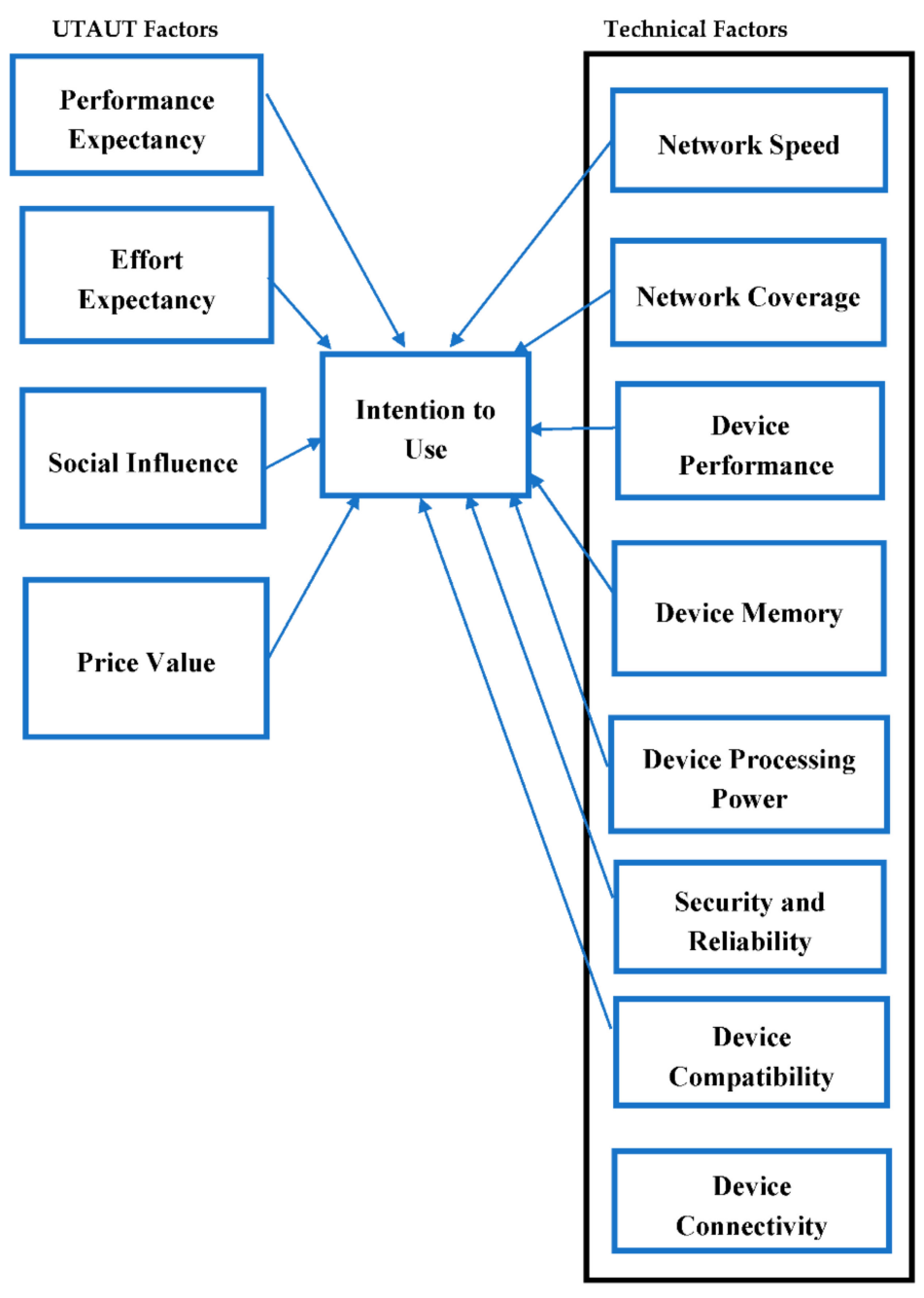

Figure 2. Proposed model.

\section{Research Methodology}

The present study aims to extend the UTAUT model that measures student acceptance towards using mobile phones as a learning tool. This model incorporates the technical factors that may affect the users' intention to adopt such technology.

\subsection{Research Approach}

In measuring the proposed model and hypotheses, a questionnaire was developed, which was adapted from several sources (see Appendix A). In a review delineating the use of acceptance models in technology, surveys were the most used instrument of the last ten years [23]. The questionnaire was divided into two parts: One part measured the original UTAUT factors, and the other section measured the technical factors. The scale used in this study was a 5-point Likert. This scale was chosen due to its popularity and use by researchers and is considered as one of the best scales to measure responses [55]. The scales ranged between 1 = 'strongly agree' to 5 = 'strongly disagree'. Some researchers have also recommended conducting a content validity index (CVI) test to confirm the suitability of the indicators for the associated factors [56]. The questionnaire was distributed to five experts in this field and was updated based on their comments and feedback. Some items have been excluded, and others have been corrected. Appendix B reflects the CVI results.

The questionnaire was translated into Arabic by an accredited office employing the back-translation method, which enhanced the goodness of the document [57], before being translated back into its original language (English) by a language specialist to ensure 
accuracy. Generally, in new or modified models, the researcher should undertake a face validity test [58]. We applied one in this study by distributing the questionnaire to a representative sample (i.e., a group of students) to undertake the test. The result confirmed the validity of the questionnaire. A pilot test was then conducted based on the results in which several items in the questionnaire were modified.

\subsection{Sampling and Data Collections}

The primary sample in this study was undergraduate and postgraduate students attending the University of Hail in the Kingdom of Saudi Arabia. The questionnaire was distributed electronically through the Information Technology Department at the University of Hail in order to reach the largest number of students. This provided the opportunity to distribute the electronic questionnaires to recipients and registering their interest to participate in the study via e-mail to avoid repeated responses from the same person. A total of 612 responses were received from recipients representing students enrolled at the university and from several professional and academic specializations for each gender and from different backgrounds. The selection was random by sending the survey electronically to all university students through the Deanship of IT and E-Learning. Table 1 shows a summary of the descriptive information of the respondents of this study.

Table 1. Descriptive information.

\begin{tabular}{cccc}
\hline Characters & & Frequency & Percent (\%) \\
\hline \multirow{2}{*}{ Gender } & Male & 230 & $38 \%$ \\
& Female & 382 & $62 \%$ \\
\hline \multirow{4}{*}{ Age Level } & From 15 To 19 & 130 & $21 \%$ \\
& From 20 To 24 & 398 & $65 \%$ \\
& From 25 To 29 & 61 & $10 \%$ \\
& Other Age & 23 & $4 \%$ \\
\hline \multirow{3}{*}{ Income } & Very Good & 164 & $27 \%$ \\
& Good & 210 & $34 \%$ \\
& Medium & 190 & $31 \%$ \\
Study & Poor & 48 & $8 \%$ \\
Location & University Main Campus & 551 & $90 \%$ \\
& University's External Branches & 61 & $10 \%$ \\
\hline
\end{tabular}

\section{Data Analysis and Results}

Structural equation modelling (SEM) was used to test the hypotheses. This technique has been used by researchers, which helps to overcome the weakness of conventional methods in the statistical analysis. There are two types of techniques for SEM, covariancebased SEM (CB-SEM) and partial least squares (PLS-SEM) that were used in this study since SEM can handle both reflective and formative measurement models relatively easily and be used with constructs having one item. This method is employed by many researchers in a variety of studies [56]. Smart-PLS version 3.2.9 software was also used, combining sophisticated statistical methods with an easy-to-use, flexible, and fast user interface [59]. In addition, there are several reasons for using Smart-PLS that include the following:

1. Certain factors in the proposed model are predictive factors (in addition to confirming other factors which can be used for other applications, such as AMOS).

2. It can be used when the distribution is abnormal.

3. It can be used when elements are associated with less than three factors.

4. Smart-PLS can deal with data extracted from a small sample or a large sample [60].

According to the approach proposed by Anderson et al. 1988, a two-step modelling approach was adopted in this study to evaluate the measurement model and the structural model, along with testing the theory [61]. Analysis of the measurement model was undertaken via a validity and reliability test, followed by the assessment of the structural model. 


\subsection{Measurement Model Analysis}

The measurement model analysis was divided into two parts: Part A, convergent validity and Part $B$, discriminant validity. In the first section, three parts were tested: Average variance extracted (AVE), composite reliability (CR), and Cronbach's alpha. Cronbach's alpha provides a reliability evaluation based on the relationships that are exchanged between the index variables under study [56]. This test has a value of between 0 and 1 , and when the result is closer to 1 , higher reliability is achieved. If the result is 0.9 or higher, the reliability is very high, while if the result is less than 0.5 , the reliability is low. In this study, the results for all indicators were relatively high, and the lowest for these indicators was 0.68 , which is still considered within acceptable limits [62].

In addition, due to some of the limitations associated with Cronbach's alpha, it is preferable to perform more reliability tests. This induces the need to use CR, which considers other indicator variables and also its results are limited to 0 and 1 . Moreover, it is considered acceptable when a value between 0.6 and 0.7 is obtained and satisfactory if it is between 0.7 and 0.9 [56]. The results of the CR test in this study were higher than 0.81 , which is considered satisfactory and supportive at the same time. The third section of convergent validity is AVE, which measures the level of variance that can be captured by factors towards the level due to the result of measurement error. If the result is greater than 0.7 , it is considered highly reliable, and if it is within 0.5 to 0.7 , it is considered acceptable [63]. In this study, most of the results of the AVE in the measurement model test were between 0.65 and 0.89 , which is considered to be highly reliable except only one factor that had a result of 0.525 , though it is still also considered acceptable. Table 2 shows the results for AVE, CR, and Cronbach's alpha.

Table 2. Convergent validity results.

\begin{tabular}{cccc}
\hline Constructs & $\begin{array}{c}\text { Cronbach's } \\
\text { Alpha }\end{array}$ & Composite Reliability & $\begin{array}{c}\text { Average Variance } \\
\text { Extracted (AVE) }\end{array}$ \\
\hline Device Compatibility & 0.865 & 0.936 & 0.879 \\
\hline Device Connectivity & 0.766 & 0.866 & 0.685 \\
\hline Device Memory & 0.827 & 0.897 & 0.745 \\
\hline Device Performance & 0.939 & 0.961 & 0.892 \\
\hline Device Processing Power & 0.831 & 0.887 & 0.863 \\
\hline Effort Expectancy & 0.936 & 0.959 & 0.835 \\
\hline Intention to Use & 0.901 & 0.938 & 0.525 \\
\hline Network Coverage & 0.688 & 0.812 & 0.880 \\
\hline Network Speed & 0.864 & 0.936 & 0.673 \\
\hline Performance Expectancy & 0.879 & 0.911 & 0.750 \\
\hline Price Value & 0.834 & 0.900 & 0.653 \\
\hline Security and Reliability & 0.822 & 0.882 & 0.797 \\
\hline Social Influence & 0.872 & 0.921 & \\
\hline
\end{tabular}

The second section of the measurement model analysis was the discriminate validity (DV) test that consists of three phases, Fornell-Larcker criterion, cross-loadings, and the Heterotrait-Monotrait ratio (HTMT). This type of test can be used by researchers to confirm DV [37]. The first of these steps, traditionally employed by researchers to ensure the validity of the indicators in the model, is cross-loadings [56]. In this section, the cross-loadings of any factor should be the strongest in its area compared to the rest of the other factors for it to be valid [64]. All the factors tested in this study showed their strength in their respective regions, as shown in Table 3.

The second part of the DV evaluation was the Fornell-Larcker criterion, a method used to compare the relationship between underlying factors and the square root of the AVE [56]. This evaluation provides an image of the DV result in which the factor in this 
area should be stronger than the results of the other factors [65]. Table 4 shows the results of Fornell-Larcker criterion, in which it can be clearly seen that each of the factors in its area is stronger than the remaining factors, whether on the left or below it.

Table 3. Factors' items cross-loadings results.

\begin{tabular}{|c|c|c|c|c|c|c|c|c|c|c|c|c|c|}
\hline Constructs & DC & DCO & DM & DP & DPP & EE & IU & NC & NS & PE & PV & SRML & SI \\
\hline \multirow{2}{*}{$\begin{array}{c}\text { Device } \\
\text { Compatibility (DC) }\end{array}$} & 0.920 & 0.669 & 0.711 & 0.608 & 0.682 & 0.525 & 0.563 & 0.639 & 0.726 & 0.651 & 0.503 & 0.616 & 0.409 \\
\hline & 0.955 & 0.656 & 0.604 & 0.603 & 0.610 & 0.564 & 0.743 & 0.550 & 0.687 & 0.719 & 0.515 & 0.685 & 0.481 \\
\hline \multirow{3}{*}{$\begin{array}{c}\text { Device } \\
\text { Connectivity (DCO) }\end{array}$} & 0.647 & 0.908 & 0.545 & 0.601 & 0.524 & 0.556 & 0.642 & 0.548 & 0.602 & 0.656 & 0.568 & 0.648 & 0.549 \\
\hline & 0.580 & 0.841 & 0.409 & 0.693 & 0.475 & 0.571 & 0.515 & 0.583 & 0.667 & 0.639 & 0.529 & 0.530 & 0.427 \\
\hline & 0.513 & 0.722 & 0.527 & 0.410 & 0.619 & 0.477 & 0.479 & 0.346 & 0.420 & 0.310 & 0.390 & 0.510 & 0.240 \\
\hline \multirow{3}{*}{$\begin{array}{l}\text { Device Memory } \\
\text { (DM) }\end{array}$} & 0.630 & 0.499 & 0.923 & 0.490 & 0.674 & 0.352 & 0.636 & 0.558 & 0.606 & 0.515 & 0.536 & 0.538 & 0.433 \\
\hline & 0.509 & 0.479 & 0.868 & 0.366 & 0.648 & 0.351 & 0.554 & 0.510 & 0.514 & 0.417 & 0.539 & 0.519 & 0.442 \\
\hline & 0.666 & 0.587 & 0.793 & 0.540 & 0.456 & 0.428 & 0.477 & 0.655 & 0.806 & 0.489 & 0.539 & 0.606 & 0.385 \\
\hline \multirow{3}{*}{$\begin{array}{c}\text { Device } \\
\text { Performance (DP) }\end{array}$} & 0.558 & 0.664 & 0.486 & 0.929 & 0.391 & 0.601 & 0.464 & 0.568 & 0.550 & 0.723 & 0.482 & 0.448 & 0.539 \\
\hline & 0.602 & 0.664 & 0.506 & 0.973 & 0.494 & 0.658 & 0.509 & 0.526 & 0.578 & 0.783 & 0.485 & 0.478 & 0.498 \\
\hline & 0.667 & 0.627 & 0.524 & 0.931 & 0.516 & 0.579 & 0.456 & 0.513 & 0.565 & 0.736 & 0.423 & 0.494 & 0.524 \\
\hline \multirow{4}{*}{$\begin{array}{l}\text { Device Processing } \\
\text { Power (DPP) }\end{array}$} & 0.550 & 0.503 & 0.560 & 0.323 & 0.823 & 0.264 & 0.592 & 0.300 & 0.406 & 0.391 & 0.537 & 0.503 & 0.271 \\
\hline & 0.498 & 0.520 & 0.595 & 0.448 & 0.846 & 0.347 & 0.486 & 0.384 & 0.548 & 0.421 & 0.454 & 0.493 & 0.335 \\
\hline & 0.433 & 0.438 & 0.415 & 0.280 & 0.833 & 0.261 & 0.375 & 0.237 & 0.338 & 0.260 & 0.369 & 0.480 & 0.252 \\
\hline & 0.704 & 0.616 & 0.653 & 0.542 & 0.752 & 0.477 & 0.501 & 0.577 & 0.721 & 0.584 & 0.531 & 0.663 & 0.403 \\
\hline \multirow{3}{*}{$\begin{array}{l}\text { Effort Expectancy } \\
\text { (EE) }\end{array}$} & 0.501 & 0.568 & 0.395 & 0.590 & 0.395 & 0.932 & 0.431 & 0.349 & 0.442 & 0.628 & 0.307 & 0.540 & 0.248 \\
\hline & 0.496 & 0.657 & 0.368 & 0.636 & 0.383 & 0.936 & 0.408 & 0.339 & 0.442 & 0.565 & 0.393 & 0.522 & 0.287 \\
\hline & 0.635 & 0.603 & 0.446 & 0.613 & 0.400 & 0.958 & 0.492 & 0.381 & 0.553 & 0.676 & 0.353 & 0.618 & 0.318 \\
\hline \multirow{3}{*}{$\begin{array}{l}\text { Intention to Use } \\
\text { (IU) }\end{array}$} & 0.680 & 0.647 & 0.599 & 0.488 & 0.606 & 0.509 & 0.951 & 0.554 & 0.643 & 0.595 & 0.577 & 0.643 & 0.496 \\
\hline & 0.702 & 0.681 & 0.678 & 0.481 & 0.584 & 0.454 & 0.925 & 0.582 & 0.667 & 0.608 & 0.556 & 0.675 & 0.529 \\
\hline & 0.550 & 0.483 & 0.490 & 0.411 & 0.493 & 0.323 & 0.864 & 0.539 & 0.461 & 0.507 & 0.550 & 0.547 & 0.510 \\
\hline \multirow{4}{*}{$\begin{array}{c}\text { Network Coverage } \\
\text { (NC) }\end{array}$} & 0.550 & 0.597 & 0.534 & 0.505 & 0.452 & 0.424 & 0.437 & 0.702 & 0.700 & 0.551 & 0.513 & 0.452 & 0.383 \\
\hline & 0.155 & 0.142 & 0.225 & 0.160 & 0.099 & 0.021 & 0.309 & 0.529 & 0.015 & 0.194 & 0.114 & 0.178 & 0.333 \\
\hline & 0.482 & 0.327 & 0.464 & 0.399 & 0.319 & 0.231 & 0.492 & 0.799 & 0.422 & 0.403 & 0.357 & 0.387 & 0.273 \\
\hline & 0.549 & 0.603 & 0.618 & 0.516 & 0.425 & 0.359 & 0.506 & 0.830 & 0.703 & 0.530 & 0.538 & 0.446 & 0.312 \\
\hline \multirow{2}{*}{$\begin{array}{l}\text { Network Speed } \\
\text { (NS) }\end{array}$} & 0.739 & 0.665 & 0.729 & 0.578 & 0.587 & 0.496 & 0.634 & 0.680 & 0.943 & 0.568 & 0.647 & 0.634 & 0.386 \\
\hline & 0.662 & 0.616 & 0.637 & 0.541 & 0.589 & 0.464 & 0.587 & 0.594 & 0.933 & 0.611 & 0.600 & 0.609 & 0.329 \\
\hline \multirow{5}{*}{$\begin{array}{c}\text { Performance } \\
\text { Expectancy (PE) }\end{array}$} & 0.658 & 0.519 & 0.418 & 0.605 & 0.389 & 0.669 & 0.372 & 0.406 & 0.570 & 0.791 & 0.289 & 0.545 & 0.352 \\
\hline & 0.613 & 0.629 & 0.510 & 0.708 & 0.508 & 0.590 & 0.553 & 0.527 & 0.595 & 0.871 & 0.483 & 0.459 & 0.355 \\
\hline & 0.560 & 0.526 & 0.386 & 0.575 & 0.362 & 0.559 & 0.605 & 0.442 & 0.483 & 0.849 & 0.335 & 0.489 & 0.510 \\
\hline & 0.625 & 0.465 & 0.505 & 0.610 & 0.464 & 0.416 & 0.474 & 0.495 & 0.514 & 0.745 & 0.487 & 0.411 & 0.434 \\
\hline & 0.591 & 0.564 & 0.438 & 0.756 & 0.418 & 0.522 & 0.513 & 0.575 & 0.439 & 0.841 & 0.313 & 0.407 & 0.607 \\
\hline \multirow{3}{*}{ Price Value (PV) } & 0.312 & 0.333 & 0.418 & 0.290 & 0.376 & 0.155 & 0.411 & 0.350 & 0.343 & 0.255 & 0.802 & 0.430 & 0.376 \\
\hline & 0.513 & 0.629 & 0.652 & 0.482 & 0.591 & 0.422 & 0.538 & 0.544 & 0.728 & 0.482 & 0.863 & 0.547 & 0.262 \\
\hline & 0.546 & 0.571 & 0.527 & 0.475 & 0.551 & 0.352 & 0.616 & 0.513 & 0.612 & 0.445 & 0.929 & 0.562 & 0.376 \\
\hline \multirow{4}{*}{$\begin{array}{l}\text { Security and } \\
\text { Reliability }\end{array}$} & 0.560 & 0.554 & 0.535 & 0.484 & 0.421 & 0.493 & 0.608 & 0.521 & 0.608 & 0.469 & 0.556 & 0.764 & 0.472 \\
\hline & 0.543 & 0.505 & 0.418 & 0.338 & 0.448 & 0.430 & 0.474 & 0.439 & 0.516 & 0.468 & 0.405 & 0.814 & 0.407 \\
\hline & 0.518 & 0.516 & 0.499 & 0.340 & 0.579 & 0.468 & 0.536 & 0.257 & 0.406 & 0.357 & 0.418 & 0.791 & 0.391 \\
\hline & 0.622 & 0.624 & 0.580 & 0.434 & 0.682 & 0.526 & 0.569 & 0.449 & 0.593 & 0.500 & 0.528 & 0.860 & 0.368 \\
\hline \multirow{3}{*}{ Social Influence (SI) } & 0.368 & 0.406 & 0.442 & 0.469 & 0.342 & 0.228 & 0.547 & 0.366 & 0.325 & 0.501 & 0.398 & 0.418 & 0.894 \\
\hline & 0.484 & 0.481 & 0.426 & 0.496 & 0.389 & 0.254 & 0.495 & 0.420 & 0.356 & 0.494 & 0.316 & 0.508 & 0.924 \\
\hline & 0.438 & 0.472 & 0.436 & 0.512 & 0.311 & 0.342 & 0.446 & 0.389 & 0.346 & 0.493 & 0.311 & 0.442 & 0.858 \\
\hline
\end{tabular}


The third part of the DV evaluation was the Heterotrait-Monotrait ratio (HTMT), which measures the average of all index relationships between the factors that measure the other factors and is one of the tests that must be conducted to overcome the limitations of the Fornell-Larcker criterion and cross-loading assessments. HTMT validity is weak when its results are greater than 0.9 and becomes stronger as it becomes less than that value [56]. Table 5 shows the results of HTMT, which shows that all results for factors, whether general factors or technical factors, are smaller than 0.9 , thus emphasizing the effectiveness of the measurement model.

Table 4. Fornell-Larcker criterion.

\begin{tabular}{|c|c|c|c|c|c|c|c|c|c|c|c|c|c|}
\hline Constructs & DC & DCO & DM & DP & DPP & EE & IU & NC & NS & PE & PV & SRML & SI \\
\hline Device Compatibility & 0.938 & & & & & & & & & & & & \\
\hline Device Connectivity & 0.704 & 0.827 & & & & & & & & & & & \\
\hline Device Memory & 0.692 & 0.597 & 0.863 & & & & & & & & & & \\
\hline Device Performance & 0.644 & 0.690 & 0.534 & 0.945 & & & & & & & & & \\
\hline Device Processing Power & 0.682 & 0.645 & 0.695 & 0.495 & 0.814 & & & & & & & & \\
\hline Effort Expectancy & 0.582 & 0.645 & 0.430 & 0.650 & 0.417 & 0.942 & & & & & & & \\
\hline Intention to Use & 0.708 & 0.666 & 0.649 & 0.505 & 0.616 & 0.474 & 0.914 & & & & & & \\
\hline Network Coverage & 0.626 & 0.600 & 0.657 & 0.567 & 0.468 & 0.379 & 0.611 & 0.725 & & & & & \\
\hline Network Speed & 0.748 & 0.684 & 0.730 & 0.597 & 0.627 & 0.512 & 0.652 & 0.681 & 0.938 & & & & \\
\hline Performance Expectancy & 0.734 & 0.660 & 0.547 & 0.792 & 0.520 & 0.664 & 0.626 & 0.597 & 0.628 & 0.821 & & & \\
\hline Price Value & 0.542 & 0.605 & 0.620 & 0.491 & 0.594 & 0.372 & 0.613 & 0.551 & 0.666 & 0.467 & 0.866 & & \\
\hline Security and Reliability & 0.697 & 0.685 & 0.636 & 0.501 & 0.661 & 0.598 & 0.683 & 0.520 & 0.663 & 0.557 & 0.598 & 0.808 & \\
\hline Social Influence & 0.479 & 0.505 & 0.487 & 0.550 & 0.390 & 0.303 & 0.559 & 0.438 & 0.382 & 0.556 & 0.386 & 0.509 & 0.892 \\
\hline
\end{tabular}

Device Compatibility = DC, Device Connectivity $=$ DCO, Device Memory $=$ DM, Device Performance $=$ DP, Device Processing Power $=$ DPP, Effort Expectancy $=$ EE, intention to Use $=I U$, Network Coverage $=$ NC, Network Speed $=$ NS, Performance Expectancy $=$ PE Price Value $=$ PV, Security and Reliability of Mobile Learning on Devices $=$ SRML, Social Influence $=$ SI .

Table 5. Heterotrait-Monotrait ratio (HTMT) results.

\begin{tabular}{|c|c|c|c|c|c|c|c|c|c|c|c|c|c|}
\hline Constructs & DC & DCO & DM & DP & DPP & EE & IU & NC & NS & PE & PV & SRML & SI \\
\hline \multicolumn{14}{|l|}{ Device Compatibility } \\
\hline Device Connectivity & 0.866 & & & & & & & & & & & & \\
\hline Device Memory & 0.835 & 0.762 & & & & & & & & & & & \\
\hline Device Performance & 0.717 & 0.812 & 0.613 & & & & & & & & & & \\
\hline Device Processing Power & 0.799 & 0.812 & 0.814 & 0.553 & & & & & & & & & \\
\hline Effort Expectancy & 0.639 & 0.767 & 0.494 & 0.693 & 0.469 & & & & & & & & \\
\hline Intention to Use & 0.784 & 0.789 & 0.741 & 0.546 & 0.690 & 0.508 & & & & & & & \\
\hline Network Coverage & 0.791 & 0.792 & 0.858 & 0.684 & 0.585 & 0.454 & 0.771 & & & & & & \\
\hline Network Speed & 0.869 & 0.838 & 0.879 & 0.663 & 0.730 & 0.565 & 0.731 & 0.846 & & & & & \\
\hline Performance Expectancy & 0.849 & 0.790 & 0.649 & 0.873 & 0.597 & 0.737 & 0.687 & 0.750 & 0.729 & & & & \\
\hline Price Value & 0.621 & 0.733 & 0.744 & 0.542 & 0.685 & 0.406 & 0.696 & 0.695 & 0.761 & 0.529 & & & \\
\hline Security and Reliability & 0.818 & 0.854 & 0.772 & 0.563 & 0.792 & 0.673 & 0.783 & 0.670 & 0.779 & 0.661 & 0.707 & & \\
\hline Social Influence & 0.549 & 0.605 & 0.574 & 0.611 & 0.453 & 0.339 & 0.627 & 0.585 & 0.440 & 0.629 & 0.453 & 0.600 & \\
\hline
\end{tabular}

Device Compatibility = DC, Device Connectivity = DCO, Device Memory = DM, Device Performance $=$ DP, Device Processing Power $=$ DPP, Effort Expectancy = EE, intention to Use $=$ IU, Network Coverage $=$ NC, Network Speed = NS, Performance Expectancy $=$ PE Price Value $=$ PV, Security and Reliability of Mobile Learning on Devices $=$ SRML, Social Influence $=$ SI . 


\subsection{Assessment of The Structural Model}

Assessing the structural model offers researchers the ability to test the capability of a proposed model to predict the factors associated with it by obtaining results that confirm this [56]. In this paper, the path coefficient for the proposed model and the $R$-squared were tested to confirm the results of the proposed model, an extension of the UTAUT model developed by Venkatesh et al. (2003). Bootstrapping was used to obtain the path coefficient for the factors and validation of the model. Bootstrapping is used to measure the ability of indicators to effectively participate in the associated factor first when the distribution is normal [66]. The program used to evaluate the structural model was SmartPLS 3.2. The path coefficient measures the hypotheses used to describe the factors by showing the $p$-value error rate [56]. Factors that achieve an error ratio of less than 0.05 are considered significant, and if greater than 0.05 , the relationship is not considered important or effective [59]. The significance table for the p-value is presented in Table 7 [67].

The $p$-value tests show that, overall, the factors are significant, especially the technical factors, in which 9 of the 12 hypotheses were supported. The influence of device performance, device compatibility, network speed and price value on the intention to use mobile learning were very significant. In addition, the influence of network coverage on the intention to use mobile learning was high as the relationship was very significant $(p$-value $=0.010)$. Device memory, device connectivity, effort expectancy, and performance expectancy also had a significant influence on the intention to use mobile devices in the learning process ( $p$-value $<0.05)$. Three hypotheses in which the results were not supported were security and reliability of m-learning on devices, device processing power, and social influence. Figure 3 and Table 6 below show the path coefficient results.

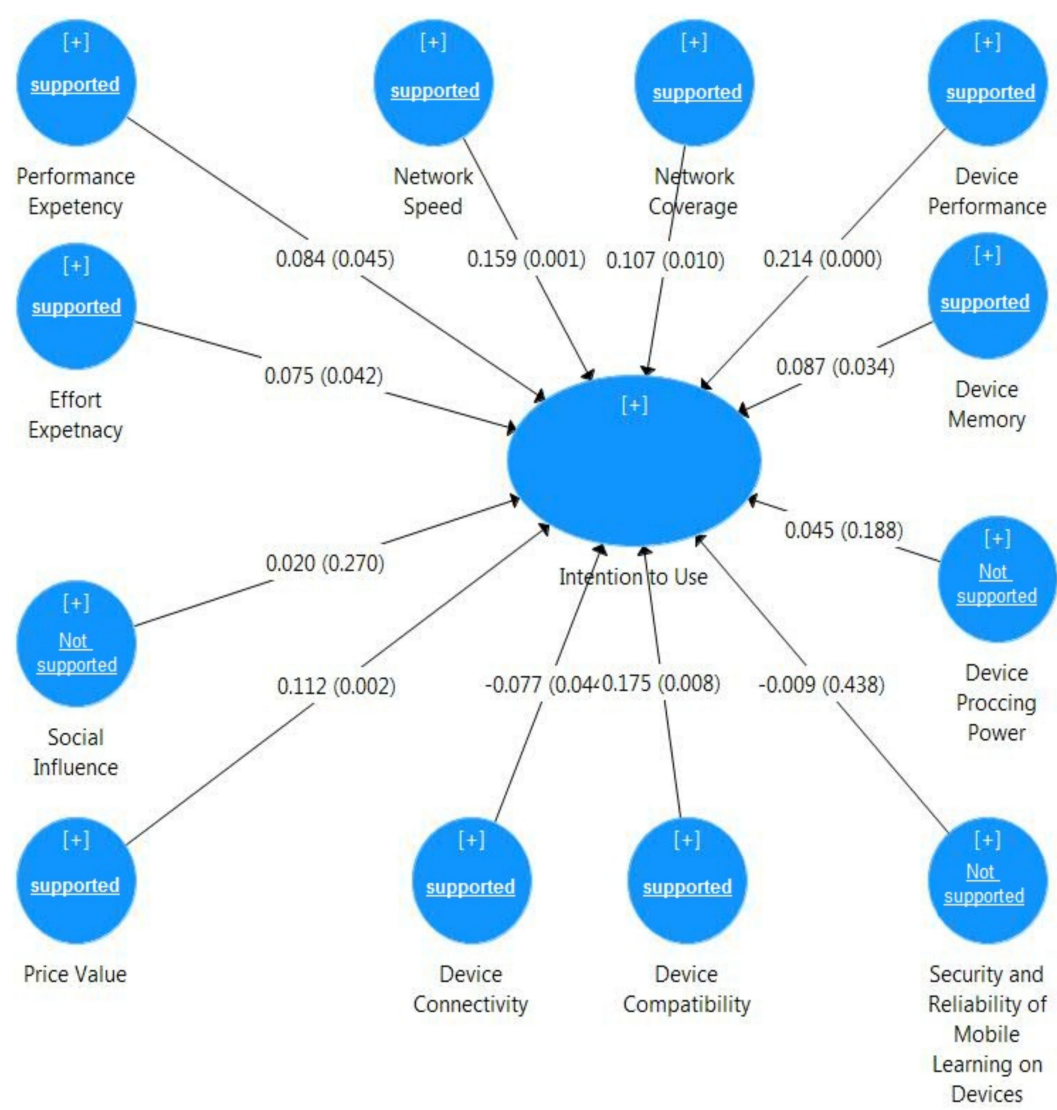

Figure 3. Results of Path coefficient analysis. 
Table 6. Path coefficient results.

\begin{tabular}{|c|c|c|c|c|c|}
\hline Constructs & $\begin{array}{l}\text { Original } \\
\text { Sample }\end{array}$ & $\begin{array}{c}\text { Sample } \\
\text { Mean (M) }\end{array}$ & $\begin{array}{l}\text { Standard } \\
\text { Deviation } \\
(\text { STDEV) }\end{array}$ & $p$ Values & Status \\
\hline $\begin{array}{l}\text { Device Compatibility } \\
\text {-> Intention to Use }\end{array}$ & 0.175 & 0.170 & 0.072 & 0.008 & supported \\
\hline $\begin{array}{l}\text { Device Connectivity -> } \\
\text { Intention to Use }\end{array}$ & -0.077 & -0.074 & 0.045 & 0.044 & supported \\
\hline $\begin{array}{l}\text { Device Memory -> } \\
\text { Intention to Use }\end{array}$ & 0.087 & 0.088 & 0.048 & 0.034 & supported \\
\hline $\begin{array}{l}\text { Device Performance -> } \\
\text { Intention to Use }\end{array}$ & 0.214 & 0.207 & 0.052 & 0.000 & supported \\
\hline $\begin{array}{l}\text { Device Processing } \\
\text { Power -> Intention to } \\
\text { Use }\end{array}$ & 0.045 & 0.047 & 0.051 & 0.188 & $\begin{array}{c}\text { not } \\
\text { supported }\end{array}$ \\
\hline $\begin{array}{l}\text { Effort Expectancy -> } \\
\text { Intention to Use }\end{array}$ & 0.075 & 0.074 & 0.043 & 0.042 & supported \\
\hline $\begin{array}{l}\text { Network Coverage -> } \\
\text { Intention to Use }\end{array}$ & 0.107 & 0.106 & 0.046 & 0.010 & supported \\
\hline $\begin{array}{l}\text { Network Speed -> } \\
\text { Intention to Use }\end{array}$ & 0.159 & 0.163 & 0.052 & 0.001 & supported \\
\hline $\begin{array}{c}\text { Performance } \\
\text { Expectancy -> } \\
\text { Intention to Use }\end{array}$ & 0.084 & 0.085 & 0.049 & 0.045 & supported \\
\hline $\begin{array}{l}\text { Price Value -> } \\
\text { Intention to Use }\end{array}$ & 0.112 & 0.114 & 0.040 & 0.002 & supported \\
\hline $\begin{array}{l}\text { Security and } \\
\text { Reliability of Mobile } \\
\text { Learning on Devices -> } \\
\text { Intention to Use }\end{array}$ & -0.009 & -0.010 & 0.055 & 0.438 & $\begin{array}{c}\text { not } \\
\text { supported }\end{array}$ \\
\hline $\begin{array}{l}\text { Social Influence -> } \\
\text { Intention to Use }\end{array}$ & 0.020 & 0.022 & 0.032 & 0.270 & $\begin{array}{c}\text { not } \\
\text { supported }\end{array}$ \\
\hline
\end{tabular}

Table 7. Significance of $p$-Value.

\begin{tabular}{ccc}
\hline$p$-Value Results & Transpiration & Shortcut \\
\hline$<0.0001$ & Extremely significant & $* * * *$ \\
\hline 0.0001 to 0.001 & Extremely significant & $* * *$ \\
\hline 0.001 to 0.01 & Very significant & $* *$ \\
\hline 0.01 to 0.05 & Significant & $*$ \\
\hline$\geq 0.05$ & Not significant & $\mathrm{ns}$ \\
\hline
\end{tabular}

Nevertheless, one of the most frequently used evaluations in measuring the structural model is the $R^{2}$ coefficient of determination, which measures the strength of the predictive model through the factors it provides [56]. The proposed model succeeded in describing the variance of factors affecting intention to use m-learning by obtaining $63 \%$. Table 8 shows the results of the $R^{2}$ analysis. 
Table 8. $R$-Squared results.

\begin{tabular}{ccc}
\hline \multicolumn{3}{c}{ R-Squared of the Endogenous Latent Variables } \\
\hline Constructs Relation & $R^{2}$ & Result \\
\hline Intention to Use & 0.632 & Moderate * $^{*}$
\end{tabular}

*According to Chin (1998), an R2 value of more than 0.67 is considered high, between 0.33 to 0.67 , it is considered moderate, and between 0.19 and 0.33 , it is considered weak. If it is less than 0.19 , it is rejected [46].

\section{Discussion}

The educational process over recent years has evolved to include diverse sources of learning, allowing learners to obtain knowledge from various sources easily. It is clear at the present time that there are developments in teaching methods that depend on technological means [26]. One of the most recent sources of educational learning is via mobile devices, referred to as m-learning. This study was applied to a Saudi public university, the University of Hail. The results obtained from conducting the tests on the proposed model were both good and influential. The results showed support for 9 of 12 hypotheses presented by the proposed model in this paper. Compared to the UTAUT original model, the results indicated several similarities. In the presence of some moderators [40], the effect of PE in the original model was found to be stronger for men and young workers; whereas, in the proposed model, there was a clear effect of PE on the intention of students to use mobile devices in the educational process.

Further to that, effort expectancy was shown to have a stronger influence on the original model of some user classes considering the presence of some moderators [40]. This factor was also shown to influence the proposed model on the students' intention to use m-learning. On the other hand, social influence affected some groups such as the elderly and women as found in a previous study under conditions which were found leading to this influence [40]. However, in the current study, the results showed that students do not consider SI as a factor that may affect their acceptance of this type of technique in obtaining knowledge. Regarding the technical factors that were the primary focus of this study, the results showed the influence of most of these factors on the extent of students acceptance on the inclusion of m-learning in their study life. The strongest of these factors was network speed, device performance, and device compatibility, where the influence was very high and noticeably significant. The remaining factors ranged between having a moderate effect and an acceptable level of influence, including network coverage, device memory, and device connectivity.

The exceptions that were noted in this study included security and reliability of $\mathrm{m}$-learning on devices and device processing power since these factors did not affect the students' intention towards m-learning. This may be due to two reasons, one of which is that educational materials may not always have heavy programmatic or graphic characteristics and may not require a powerful processor. In addition, the other reason may be that universities and educational institutions freely and securely provide many educational materials to students, so that students may not need to worry regarding security and reliability. However, price value, and its impact on students' intention to include m-learning in their scientific lives, was very high; this was due to the diversity of students' income levels and standard of living. As such, the proposed model succeeded in describing the variation of the factors affecting the intention to use m-learning among students at the University of Hail by obtaining $63 \%$, which is considered close to the high rate in describing the variation in the influencing factors.

\section{Conclusions}

This study proposed a new model to investigate the effect of technical factors on mobile learning usage by employing the UTAUT model. In the proposed model, the technical factors incorporated were: Device connectivity, device compatibility, device memory, device performance, device processing power, security and reliability of m- 
learning on devices, network coverage, and network speed. We used structural equation modelling (SEM) to test the formulated hypotheses on the proposed model. According to the results of the study, it was shown that the influence of device performance, device compatibility, network speed, and price value on the intention to utilize m-learning was exceptionally effective. Moreover, the influence of network coverage on the intention to utilize m-learning was high since the relationship was very significant. Likewise, device memory, device connectivity, effort expectancy and performance expectancy impacted the students' intention to incorporate smartphone devices into their learning life. However, three hypotheses were not supported: Security and reliability of m-learning on devices, device processing power, and social influence.

Accordingly, this research contributes to the body of knowledge in this field by providing a new model that leads to a better understanding of the intention of students towards applying m-learning. Based on the study's findings, Figure 4 demonstrates a guidelines diagram for the successful application of mobile learning.

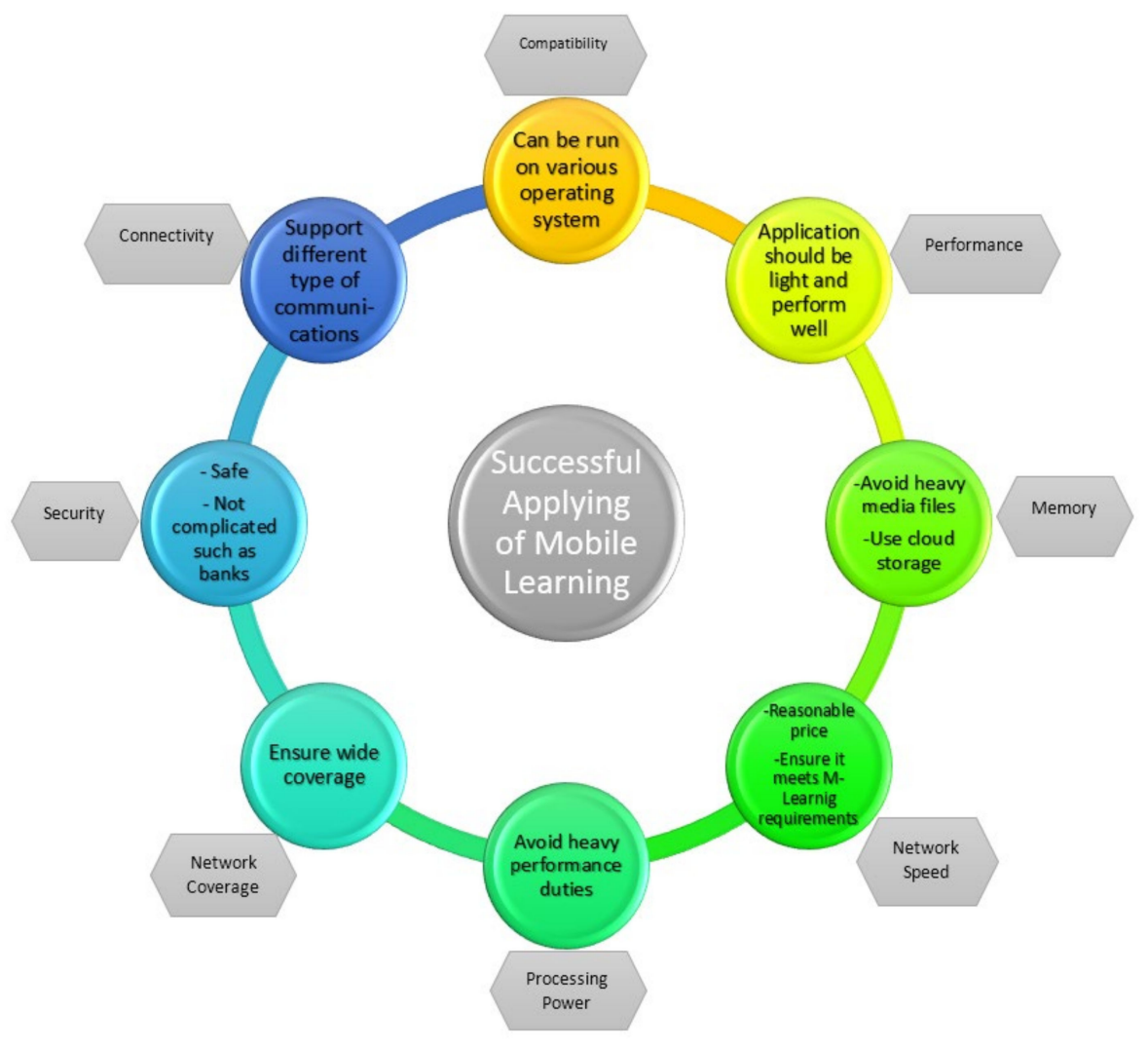

Figure 4. Guidelines for Successful application of M-learning.

In addition, this study will also provide further insight into the need for m-learning in the educational context, and the factors affecting the use of this technology. This understanding will also lead to various educational institutions and software developers to take advantage of these results to address the needs of students, the factors affecting such technology employed in educational environments and when developing applications based on the principle of m-learning. Furthermore, this model helps in the sustainability of mobile learning by knowing the factors affecting students' intention to use before applying this type of education to ensure its success and continuity.

\section{Limitations and Future Studies}

Despite several previous studies that have investigated the factors affecting students acceptance of m-learning, limited focus has been directed towards exploring the impact of 
technical factors on this type of technology, especially in the context of Arab or developing countries. Although this study provided positive results for some technical factors, limitations remain. One limitation is that this study focused on some, but not all, technical factors. Secondly, the context of this study was centered around the Kingdom of Saudi Arabia. Therefore, in progressing further study in this area, more technical factors should be included, such as display screens, sizes of display, audio devices linked to mobile phones, and other technical factors. Furthermore, the scope of the study could be extended to include other developing countries.

Author Contributions: Conceptualization, S.S.A.; methodology, S.S.A.; software, L.S.; validation, A.K., and M.A.A.; formal analysis, S.S.A.; investigation, L.S.; resources, A.K.; data curation, S.S.A.; writing-original draft preparation, S.S.A.; writing—review and editing, L.A and M.A.A.; visualization, S.S.A.; supervision, A.K.; S.Y.W. and L.S.; project administration, S.S.A.; All authors have read and agreed to the published version of the manuscript.

Funding: This research received no external funding.

Institutional Review Board Statement: Not applicable.

Informed Consent Statement: Not applicable.

Data Availability Statement: Not applicable.

Conflicts of Interest: The authors declare no conflict of interest.

\section{Appendix A}

Table A1. Questionnaire.

\begin{tabular}{|c|c|}
\hline Constructs & Items \\
\hline $\begin{array}{l}\text { Performance } \\
\text { Expectancy }\end{array}$ & $\begin{array}{l}\text { 1. I find using mobile devices useful in my daily life } \\
\text { 2. Using mobile learning helps me accomplish things more quickly } \\
\text { 3. Using mobile learning increases my knowledge } \\
\text { 4. My productivity will increase if I use Mobile learning } \\
\text { 5. If I use mobile learning I will get high marks in my course }\end{array}$ \\
\hline Effort Expectancy & $\begin{array}{l}\text { 1. Learning how to use mobile devices in education process is easy for me } \\
\text { 2. My interaction with mobile devices is clear and understandable } \\
\text { 3. I find mobile learning easy to use } \\
\text { 4. It is easy for me to become skillful when using mobile learning } \\
\text { 5. My interaction with mobile learning will be clear and understandable }\end{array}$ \\
\hline Social Influence & $\begin{array}{l}\text { 1. People who are important to me think that I should use mobile learning } \\
\text { 2. People who influence my behavior think that I should use mobile learning } \\
\text { 3. People whose opinions that I value prefer that I use mobile learning } \\
\text { 4. I think my teachers will be helpful in the use of mobile learning } \\
\text { 5. In general my university will support the use of mobile learning }\end{array}$ \\
\hline Device's performance & $\begin{array}{l}\text { 1. It would be easy for me to use my mobile devices for learning. } \\
\text { 2. If I learn through my mobile device I will increase my chances of getting more knowledge } \\
\text { 3. Using my mobile device to learn improves my performance in my courses } \\
\text { 4. Using my mobile device to learn improves my productivity in my courses } \\
\text { 5. Using my mobile device to learn improves my effectiveness in my courses }\end{array}$ \\
\hline Device's Compatibility & $\begin{array}{l}\text { 1. Learning through mobile is a good thing if it can be used with any kinds of mobile devices } \\
\text { 2. I will involve in online education if it can be used through my mobile } \\
\text { 3. I will use media files of my course if my mobile can play it } \\
\text { 4. I think my smartphone can fit with online course materials. } \\
\text { 5. If my mobile run lectures and learning materials smoothly I will continue to learn }\end{array}$ \\
\hline
\end{tabular}


Table A1. Cont.

\begin{tabular}{|c|c|}
\hline Constructs & Items \\
\hline Device's Connectivity & $\begin{array}{l}\text { 1. I will spend more time on mobile learning if I could access anywhere, anytime } \\
\text { 2. mobile learning would be useful if my device supports high-speed connectivity } \\
\text { 3. I have no problem to connect to different generations of speed ( } 3 G, 4 G \text {...el) from my device to interact } \\
\text { with online courses } \\
\text { 4. My phone has different ways to connect with other devices such as Wi-Fi and Bluetooth to share } \\
\text { knowledge } \\
\text { 5. It would be useful to have a phone that got variety of connectivity types to exchange course files with } \\
\text { my classmates. }\end{array}$ \\
\hline $\begin{array}{l}\text { Device's Security and } \\
\text { Reliability }\end{array}$ & $\begin{array}{l}\text { 1. If mobile learning protects the security and privacy of students I would use it } \\
\text { 2. It is hard to share some information on mobile learning } \\
\text { 3. Mobile learning provides features that can prevent unauthorized people from accessing private data. } \\
\text { 4. I believe it is safe to use my mobile to learn } \\
\text { 5.I think learning through my mobile will provide reliable information }\end{array}$ \\
\hline $\begin{array}{c}\text { Device's Processing } \\
\text { power }\end{array}$ & $\begin{array}{l}\text { 1. I have a powerful device to start using mobile learning } \\
\text { 2. I will accomplish more learning tasks through my mobile if it is quicker than using a classic way. } \\
\text { 3. Nowadays, smartphones are strong enough to handle mobile learning } \\
\text { 4. I believe my smart device offers a service that is superior in every way. } \\
\text { 5. I would use my phone to learn if it got high ability to deal with data }\end{array}$ \\
\hline $\begin{array}{l}\text { Device's Memory } \\
\text { capacities }\end{array}$ & $\begin{array}{l}\text { 1. I will download learning materials (Lectures, Slides ...etc.) if I have enough space in my mobile } \\
\text { 2.Lerning through mobile would be more sufficient if it comes with a large memory card } \\
\text { 3. I have no problems with downloading a big size file of my course into my phone } \\
\text { 4. It is useful to have a large memory capacity to store learning materials } \\
\text { 5.I will download more educational contents If I am able to increase my phone memory capacity }\end{array}$ \\
\hline Network's Coverage & $\begin{array}{l}\text { 1. my usage of mobile learning will increase with good network coverage } \\
\text { 2. My university provides good Wi-Fi access to the Internet. } \\
\text { 3. Public Wi-Fi help me to use my phone to learn } 4 \text {. Getting access to Internet everywhere would improve } \\
\text { my knowledge }\end{array}$ \\
\hline Network's Speed & $\begin{array}{l}\text { 1. Mobile Learning will enhance my knowledge as I get information quickly } \\
\text { 2. I intend to use mobile learning if my university provides fast Internet } \\
\text { 3. Using my phone is relatively faster to learn than using the public network } \\
\text { 4. My university provides fast access to the Internet. } \\
\text { 5. I would download more course materials on my phone if there is a fast coverage }\end{array}$ \\
\hline Price Value & $\begin{array}{l}\text { 1. mobile devices with good specifications for the purposes of learning are reasonably priced } \\
\text { 2. Mobile learning is a good value for the money } \\
\text { 3. Using my mobile devices to learn is reasonably priced compared with other learning channels like PC.. } \\
\text { 4. Using the Internet for mobile learning is good value for the money }\end{array}$ \\
\hline $\begin{array}{l}\text { Intention of use } \\
\text { M-Learning }\end{array}$ & $\begin{array}{l}\text { 1. I think I will use mobile learning } \\
\text { 2. I intend to use mobile learning. } \\
\text { 3. I plan to use mobile learning. }\end{array}$ \\
\hline
\end{tabular}




\section{Appendix B}

\begin{tabular}{|c|c|c|c|c|c|c|c|c|c|c|c|c|c|c|c|c|}
\hline & Relevance & & & Clarity & & & & & & Relevance & & & Clarity & & & \\
\hline TOTAL & No. Experic & & kappa & No. Exper ( & & dappa & Statues & ITEMS & TOTAL & No. ExpertC & & kappa & No. Expert C & & kappa & Statues \\
\hline 1 & 3 & 0.600 & 0.418 & 5 & 1 & & 1 Corrected & 32 & & 5 & 0.600 & 0.418 & 5 & 1.000 & 1.000 & 0 Excluded \\
\hline 2 & 5 & 1.000 & 1.000 & 5 & 1.000 & 1.00 & O Validated & 33 & & 5 & 1.000 & 1.000 & 5 & 1.000 & 1.000 & 0 Validated \\
\hline 3 & 4 & 0.800 & 0.763 & 5 & 1.000 & & 0 Validated & 34 & 4 & 5 & 1.000 & 1.000 & 5 & 1.000 & 1.000 & O Validated \\
\hline 4 & 4 & 0.800 & 0.763 & 5 & 0.600 & & 18 Corrected & 35 & & 5 & 0.800 & 0.763 & 5 & 0.800 & $0.76:$ & 3 Validated \\
\hline 5 & 4 & 0.800 & 0.763 & 5 & 1.000 & 1.00 & 00 Validated & 36 & & 5 & 1.000 & 1.000 & 5 & 1.000 & 1.000 & O Validated \\
\hline 6 & 5 & 1.000 & 1.000 & 5 & 1.000 & & 30 Validated & 37 & & 5 & 0.800 & 0.763 & 5 & 1.000 & 1.000 & O Validated \\
\hline 7 & 5 & 1.000 & 1.000 & 5 & 1.000 & & 00 Validated & 38 & & 5 & 1.000 & 1.000 & 5 & 0.800 & $0.76:$ & 3 Validated \\
\hline 8 & 5 & 1.000 & 1.000 & 5 & 1.000 & 1.00 & O Validated & 39 & & 5 & 1.000 & 1.000 & 5 & 0.800 & $0.766^{\circ}$ & 3 Validated \\
\hline 9 & 5 & 1.000 & 1.000 & 5 & 1.000 & 1.00 & O Validated & 40 & & 5 & 1.000 & 1.000 & 5 & 0.800 & 0.768 & 3 Validated \\
\hline 10 & 5 & 1.000 & 1.000 & 5 & 0.800 & & 63 Validated & 41. & & 5 & 1.000 & 1.000 & 5 & 1.000 & 1.000 & 0 Validated \\
\hline 11 & 4 & 0.800 & 0.763 & 5 & 0.800 & & 63 Validated & 42 & & 5 & 1.000 & 1.000 & 5 & 1.000 & 1.000 & 0 Validated \\
\hline 12 & 4 & 0.800 & 0.763 & 5 & 0.800 & & 33 Validated & 43 & & 5 & 1.000 & 1.000 & 5 & 1.000 & 1.000 & 0 Validated \\
\hline 13 & 5 & 1.000 & 1.000 & 5 & 0.800 & & 33 Validated & 44 & & 5 & 1.000 & 1.000 & 5 & 1.000 & 1,000 & O Validated \\
\hline 14 & 5 & 1.000 & 1.000 & 5 & 1.000 & & 00 Validated & 45. & & 5 & 1.000 & 1.000 & 5 & 1.000 & 1.000 & O Validated \\
\hline 15 & 4 & 0.800 & 0.763 & 5 & 1.000 & & 00 Validated & 46. & & 5 & 1.000 & 1.000 & 5 & 0.800 & $0.76:$ & 3 Validated \\
\hline 16 & 3 & 0.600 & 0.418 & 5 & 0.800 & & 63 Excluded & 47 & & 5 & 1.000 & 1.000 & 5 & 1.000 & 1.000 & 0 Validated \\
\hline 17 & 4 & 0.800 & 0.763 & 5 & 0.800 & 0.76 & 63 Validated & 48 & & 5 & 1.000 & 1.000 & 5 & 1.000 & 1.000 & O Validated \\
\hline 18 & 4 & 0.800 & 0.763 & 5 & 1.000 & 1.00 & 0 Validated & 49 & & 5 & 1.000 & 1.000 & 5 & 0.600 & 0.418 & 8 Corrected \\
\hline 19 & 4 & 0.800 & 0.763 & 5 & 0.800 & & 63 Validated & 50 & & 5 & 0.800 & 0.763 & 5 & 1.000 & 1.000 & 0 Validated \\
\hline 20 & 4 & 0.800 & 0.763 & 4 & 1.000 & 1.00 & 0 Validated & 51 & & 5 & 1.000 & 1.000 & 5 & 1.000 & 1.000 & O Validated \\
\hline 21 & 5 & 1.000 & 1.000 & 5 & 0.600 & 0.41 & 18 Corrected & 52 & & 5 & 1.000 & 1.000 & 5 & 1.000 & 1.000 & O Validated \\
\hline 22 & 5 & 1.000 & 1.000 & 5 & 1.000 & 1.00 & 00 Validated & 53 & & 5 & 1.000 & 1.000 & 5 & 1.000 & 1,000 & O Validated \\
\hline 23 & 5 & 1.000 & 1.000 & 5 & 1.000 & 1.00 & 0 Validated & 54 & & 5 & 1.000 & 1.000 & 5 & 1.000 & 1.000 & 0 Validated \\
\hline 24 & 5 & 1.000 & 1.000 & 5 & 1.000 & 1.00 & 00 Validated & 55 & & 5 & 1.000 & 1.000 & 5 & 1.000 & 1.000 & O Validated \\
\hline 25 & 5 & 1.000 & 1.000 & 5 & 0.800 & 0.76 & 53 Validated & 56 & & 4 & 0.800 & 0.763 & 5 & 0.800 & 0.762 & 3 Validated \\
\hline 26 & 5 & 1.000 & 1.000 & 5 & 1.000 & 1.00 & 0 Validated & 57 & & 5 & 1,000 & 1.000 & 5 & 0.800 & $0.76:$ & 3 Validated \\
\hline 27 & 5 & 1.000 & 1.000 & 5 & 1.000 & 1.00 & 00 Validated & 58 & & 5 & 0.800 & 0.763 & 5 & 0.600 & 0.418 & 8 Excluded \\
\hline 28 & 5 & 1.000 & 1.000 & 5 & 0.800 & 0.76 & 33 Validated & 59 & & 5 & 0.800 & 0.763 & 5 & 0.800 & $0.76 ?$ & 3 Validated \\
\hline 29 & 4 & 0.800 & 0.763 & 5 & 0.800 & 0.76 & 53 Validated & 60 & & 5 & 0.800 & 0.763 & 5 & 0.800 & $0.76 ?$ & 3 Validated \\
\hline 30 & 5 & 1.000 & 1.000 & 5 & 1.000 & 1.00 & 0 Validated & 61 & & 5 & 0.800 & 0.763 & 5 & 0.800 & 0.76 & 3 Validated \\
\hline 31 & 5 & 1.000 & 1.000 & 5 & 1.000 & 1.00 & 0 Validated & & & & & & & & & \\
\hline
\end{tabular}

Figure A1. CVI Results.

\section{References}

1. International Telecommunication Union ITU. ITU releases 2014 ICT figures. Place des Nations 1211. Geneva. Switzerland. 2014. Available online: http:/ / www.itu.int/net/pressoffice/press_releases/2014/23.aspx\#.VVcem_mqqko (accessed on 5 June 2020).

2. Almaiah, M.A.; Jalil, M.A.; Man, M. Extending the TAM to examine the effects of quality features on mobile learning acceptance. J. Comput. Educ. 2016, 3, 453-485. [CrossRef]

3. Tarhini, M.E.A. Erratum to: Factors affecting the adoption of e-learning systems in Qatar and USA: Extending the Unified Theory. Educ. Technol. Res. Dev. 2017, 65, 765-767.

4. Wentzel, P.; Lammeren, R.v.; Molendijk, M.; Bruin, S.d.; Wagtendonk, A. Using mobile technology to enhance students' educational experiences: Case Study from the EDUCAUSE Center for Applied Research. Ecar. Case Study 2005, 2, 1-22. 
5. Arshad, M.J.; Farooq, A.; Shah, A. Evolution and Development Towards 4th Generation (4G) Mobile Communication Systems. J. Am. Sci. 2010, 6, 63-68.

6. Ibrahim, M.A.; Ng, K.; Razzaly, W.; Ahmad, A.R.; Ng, M.X. Information system key success factors and student behavioral intention to use M-learning. Adv. Sci. Lett. 2017, 23, 2868-2871. [CrossRef]

7. Mobile Learning Between Desire and Dread: A Futuristic Educational Outlook, JiL Scientific Research Center (Arabic Version). Available online: http:/ / shorturl.at/hnAJ8 (accessed on 14 June 2020).

8. Almaiah, M.A.; Al Mulhem, A. Analysis of the essential factors affecting of intention to use of mobile learning applications: A comparison between universities adopters and non-adopters. Educ. Inf. Technol. 2019, 24, 1433-1468. [CrossRef]

9. Dan, F. What Is Mobile Learning and Why It's a Must-Have for Your Elearning Business? Medium Corp. 2019. Available online: https:/ / medium.com/elligense-team/what-is-mobile-learning-and-is-it-a-future-of-elearning-649edd5143 (accessed on 18 May 2020).

10. Kayode, D.J.; Alabi, A.T.; Sofoluwe, A.O.; Oduwaiye, R.O. Problems and Challenges of Mobile Learning in Nigerian University System. In Handbook of Mobile Teaching and Learning; Zhang, Y., Cristol, D., Eds.; Springer: Berlin/Heidelberg, Germany, 2019; pp. $1-15$.

11. Wagner, S.; Murphy-Hill, E. Factors That Influence Productivity: A Checklist. In Rethinking Productivity in Software Engineering; Sadowski, C., Zimmermann, T., Eds.; Apress: Berkeley, CA, USA, 2019. [CrossRef]

12. Almaiah, M.A.; Alamri, M.M. Proposing a new technical quality requirements for mobile learning applications. J. Theor. Appl. Inf. Technol. 2018, 96, 6955-6968.

13. Bidin, S.; Ziden, A. Adoption and application of mobile learning in the education industry. Procedia-Soc. Behav. Sci. 2013, 90, 720-729. [CrossRef]

14. Xyleme. Mobile Learning: Making Content Available Anytime, Anywhere. Denver. USA. 2019. Available online: https: //www.xyleme.com/mobile-learning-making-content-available-anytime-anywhere (accessed on 20 November 2019).

15. Abu-Al-Aish, A.; Love, S. Factors influencing students' acceptance of m-learning: An investigation in higher education. Int. Rev. Res. Open Distrib. Learn. 2013, 14. [CrossRef]

16. Wang, S.; Higgins, M. Limitations of mobile phone learning. Jalt Call J. 2006, 2, 3-14. [CrossRef]

17. Gedik, N.; Hanci-Karademirci, A.; Kursun, E.; Cagiltay, K. Key instructional design issues in a cellular phone-based mobile learning project. Comput. Educ. 2012, 58, 1149-1159. [CrossRef]

18. Ng, S.C.; Lui, A.K.; Ngao, S.H. An interactive mobile learning platform for teaching and learning Chinese language in secondary school environment. Commun. Comput. Inf. Sci. 2013, 407, 135-147.

19. Nguyen, L.; Barton, S.M.; Nguyen, L.T. Ipads in higher education-hype and hope. Br. J. Educ. Technol. 2015, 46, 190-203. [CrossRef]

20. Almaiah, M.A.; Al-Khasawneh, A. Investigating the main determinants of mobile cloud computing adoption in university campus. Educ. Inf. Technol. 2020, 25, 3087-3107. [CrossRef]

21. Liu, Y.; Li, H.; Carlsson, C. Factors driving the adoption of m-learning: An empirical study. Comput. Educ. 2010, 55, 1211-1219. [CrossRef]

22. Keengwe, J.; Bhargava, M. Mobile learning and integration of mobile technologies in education. Educ. Inf. Technol. 2014. [CrossRef]

23. Alghazi, S.S.; Wong, S.Y.; Kamsin, A.; Yadegaridehkordi, E.; Shuib, L. Towards Sustainable Mobile Learning: A Brief Review of the Factors Influencing Acceptance of the Use of Mobile Phones as Learning Tools. Sustainability 2020, 12, 10527. [CrossRef]

24. Pozo-Sánchez, S.; López-Belmonte, J.; Rodríguez-García, A.M.; López-Núñez, J.A. Teachers' digital competence in using and analytically managing information in flipped learning. Cult. Educ. 2020, 32, 1-35. [CrossRef]

25. Little, B. Issues in mobile learning technology. Hum. Resour. Manag. Int. Dig. 2013, 21, 26-29. [CrossRef]

26. Pozo-Sánchez, S.P.; López-Belmonte, J.; Moreno-Guerrero, A.J.; Sola, J.M.; Fuentes, A.F. Effect of Bring-Your-Own-Device Program on Flipped Learning in Higher Education Students. Sustainability 2020, 12, 3729. [CrossRef]

27. Almaiah, M.A.; Alamri, M.M.; Al-Rahmi, W. Analysis the Effect of Different Factors on the Development of Mobile Learning Applications at Different Stages of Usage. IEEE Access 2019, 8, 16139-16154. [CrossRef]

28. Almaiah, M.A.; Jalil, M.M.A.; Man, M. Empirical investigation to explore factors that achieve high quality of mobile learning system based on students' perspectives. Eng. Sci. Technol. Int. J. 2016, 19, 1314-1320. [CrossRef]

29. Almaiah, M.A.; Jalil, M.A. Investigating Students' Perceptions on Mobile Learning Services. Int. J. Interact. Mob. Technol. 2014, 8, 31. [CrossRef]

30. Almaiah, M.A.; Jalil, M.A.; Man, M. Preliminary study for exploring the major problems and activities of mobile learning system: A case study of Jordan. J. Theor. Appl. Inf. Technol. 2016, 93, 580-594.

31. Almaiah, M.A.; Alismaiel, O.A. Examination of factors influencing the use of mobile learning system: An empirical study. Educ. Inf. Technol. 2019, 24, 885-909. [CrossRef]

32. Pozo-Sánchez, S.; López-Belmonte, J.; Fernández, M.F.; López, J.A. Análisis correlacional de los factores incidentes en el nivel de competencia digital del profesorado. Rev. Electrónica Interuniv. Form. Profr. 2020, 23, 143-151. [CrossRef]

33. Almaiah, M.A.; Alyoussef, I.Y. Analysis of the Effect of Course Design, Course Content Support, Course Assessment and Instructor Characteristics on the Actual Use of E-Learning System. IEEE Access 2019, 7, 171907-171922. [CrossRef] 
34. Almaiah, M.A.; Alamri, M.M.; Al-Rahmi, W. Applying the UTAUT Model to Explain the Students' Acceptance of Mobile Learning System in Higher Education. IEEE Access 2019, 7, 174673-174686. [CrossRef]

35. Chavoshi, A.; Hamidi, H. Social, individual, technological and pedagogical factors influencing mobile learning acceptance in higher education: A case from Iran. Telemat. Inform. 2019, 38, 133-165. [CrossRef]

36. Al-Shaya, H.; Al-Eid, A. Mobile Learning: Employing Mobile Devices in the Educational Process. New Education site (arabic Version). 2018. Available online: Shorturl.at/hsAIM (accessed on 3 November 2020).

37. Davis, F.D.; Bagozzi, R.P.; Warshaw, P.R. User acceptance of computer technology: A comparison of two theoretical models. Manag. Sci. 1989, 35, 982-1003. [CrossRef]

38. Courtois, C.; Montrieux, H.; Grove, F.D.; Raes, A.; Mares, L.D.; Schellens, T. Student acceptance of tablet devices in secondary education: A three-wave longitudinal cross-lagged case study. Comput. Hum. Behav. 2014, 35, 278-286. [CrossRef]

39. Magsamen-Conrad, K.; Upadhyaya, S.; Joa, C.Y.; Dowd, J. Bridging the divide: Using UTAUT to predict multigenerational tablet adoption practices. Comput. Hum. Behav. 2015, 50, 186-196. [CrossRef] [PubMed]

40. Venkatesh, V.; Morris, M.G.; Davis, G.B.; Davis, F.D. User acceptance of information technology: Toward a unified view. Mis Q 2003, 27, 425-478. [CrossRef]

41. Almaiah, M.A. Acceptance and usage of a mobile information system services in University of Jordan. Educ. Inf. Technol. 2018, 23, 1873-1895. [CrossRef]

42. Adeboye, D. 5 Effective Uses Of Mobile Technology In The Classroom. eLearning Industry. 2016. Available online: https: / / elearningindustry.com/5-uses-mobile-technology-in-the-classroom (accessed on 10 June 2020).

43. Oyelere, S.S.; Suhonen, J.; Sutinen, E. M-Learning: A New Paradigm of Learning ICT in Nigeria. Int. J. Interact. Mob. Technol. 2016, 10, 35. [CrossRef]

44. Almaiah, M.A.; Al-Khasawneh, A.; Althunibat, A. Exploring the critical challenges and factors influencing the E-learning system usage during COVID-19 pandemic. Educ. Inf. Technol. 2020, 25, 5261-5280. [CrossRef] [PubMed]

45. Kaliisa, R.; Picard, M. A systematic review on mobile learning in higher education: The African perspective. Tojet: Turk. Online J. Educ. Technol. 2017, 16, 1-18.

46. Hamakhan, Y.T.M. An empirical investigation of e-banking in the Kurdistan region of Iraq: The moderating effect of attitude. Financ. Internet Q. 2020, 16, 45-66. [CrossRef]

47. Kumar, J.A.; Bervell, B. Google Classroom for mobile learning in higher education: Modelling the initial perceptions of students. Educ Inf Technol 2019, 24, 1793-1817. [CrossRef]

48. Alksasbeh, M.; Abuhelaleh, M.; Almaiah, M.A.; Al-Jaafreh, M.; Abu Karaka, A. Towards a Model of Quality Features for Mobile Social Networks Apps in Learning Environments: An Extended Information System Success Model. Int. J. Interact. Mob. Technol. 2019, 13, 75-93. [CrossRef]

49. Computer Hope Website; Connectivity: Salt Lake City, UT, USA. 2017. Available online: http://shorturl.at/boxMO (accessed on 14 April 2020).

50. Al Amri, M.M.; Almaiah, M.A. The Use of Mobile Gamification Technology for Sustainability Learning in Saudi Higher Education. Int. J. 2020, 9 .

51. Ojha, A. How To Protect Portable Devices? Available online: https://medium.com/@UserPrivacySignal/how-to-protectportable-devices-889f301clecf (accessed on 14 December 2020).

52. Fred, M. Introduction to Computer; Advatech Office Supplies Ltd. Soin Arcade Ground Floor, Westlands: Nairobi, Kenya, 2014.

53. Computer Hope. Available online: https://www.computerhope.com/jargon/m/memory.htm (accessed on 14 April 2020).

54. Business Dictionary. Performance from BusinessDictionary.com website. Available online: http://www.businessdictionary.com/ definition/performance.html (accessed on 14 April 2020).

55. Abdel Fattah, E. An Introduction for Descriptive and Inferential Statistics Using SPSS; Khawarezm library: Jeddah, KSA, 2008.

56. Hair, J.F.; Hult GT, M.; Ringle, C.M.; Sarstedt, M. A primer on partial least squares structural equation modeling (PLS-SEM), 2nd ed.; Sage Publications: Thousand Oaks, CA, USA, 2017.

57. Son, J. Back translation as a documentation tool. Int. J. Transl. Interpret. Res. 2018, 10, 89-100. [CrossRef]

58. Hardesty, D.M.; Bearden, W.O. The use of expert judges in scale development: Implications for improving face validity of measures of unobservable constructs. J. Bus. Res. 2004, 57, 98-107. [CrossRef]

59. Smart Pls website. Available online: https://www.smartpls.com/ (accessed on 14 April 2020).

60. Roni, S.M. How to Decide Which Package is Best for My Research "Amos" or "Smart PLS"? ResearchGate: Berlin, Germany, 2014.

61. Anderson, J.C.; Gerbing, D.W. Structural Equation Modeling in Practice: A Review and Recommended Two-Step Approach. Psychol. Bull. 1988, 103, 411-423. [CrossRef]

62. Hinton, P.R.; McMurray, I.; Brownlow, C.; Cozens, B. SPSS Explained; Routledge: Abingdon, UK, 2004.

63. Alarcón, D.; Sánchez, J.A. Assessing convergent and discriminant validity in the ADHD-R IV rating scale: User-written commands for Average Variance Extracted (AVE), Composite Reliability (CR), and Heterotrait-Monotrait ratio of correlations (HTMT). In Proceedings of the Spanish STATA Meeting, Universidad Pablo de Olavide, Sevilla, Spain, 22 October 2015.

64. Shawai, Y.G.; Almaiah, M.A. Malay Language Mobile Learning System (MLMLS) using NFC Technology. Int. J. Educ. Manag. Eng. 2018, 8, 1-7. [CrossRef]

65. Ab Hamid, M.R.; Sami, W.; Sidek, M.H.M. Discriminant Validity Assessment: Use of Fornell \& Larcker criterion versus HTMT Criterion. J. Phys. Conf. Ser. 2017, 890, 012163. [CrossRef] 
66. Armida, E.E.; Rubio-Sanchez, A. The Influence of Trust in the UTAUT Model. Cryptogr. Secur. Solut. Internet Things 2014, 162-186. [CrossRef]

67. GraaphPad. Hypothesis Testing and Statistical Significance; GraphPad Software, 2018; Available online: https://www.graphpad. $\mathrm{com} /$ guides/prism/latest/statistics/extremely_significant_results.htm (accessed on 8 February 2021). 